\title{
THE IMPORTANCE OF PRESSURIZED SUBGLACIAL WATER IN SEPARATION AND SLIDING AT THE GLACIER BED
}

\author{
By RoBERT BINDSCHADLER \\ (Oceans and Ice Branch, Code 912.1, NASA/Goddard Space Flight Center, Greenbelt, \\ Maryland 20771, U.S.A.)
}

\begin{abstract}
Aвstract. The effect of pressurized subglacial water on the sliding process is examined by a parameter called the "bed separation index". This index indicates the relative extent of cavity formation by combining the effects of variation of bed-normal stress across undulations (Kamb, 1970) and steady-state water pressure in a Röthlisberger conduit at the glacier bed. Data from three glaciers of widely varying size are used to test the correlation of the bed separation index with inferred sliding rates. For Columbia Glacier and Ice Stream B in West Antarctica it is shown that high water pressure enhances sliding. More complete data from the third test case. Variegated Glacier, are used to compare a number of possible formulations of a "sliding law". A Weertman-type power law (exponent c. 3), modified for the effect of subglacial water pressure, appears to be most preferable. Other formulations, including the "lubrication factor" hypothesis used by Budd (1975) are tentatively rejected. Consideration of the temporal variations of the "bed separation index" indicate that, on short time scales of days and weeks, variations of water pressure can dominate the sliding process. A rapid order-of-magnitude increase in water discharge causes a hundredfold transient increase in the water pressure. A bi-modal hydraulic regime is revealed for water flow transverse to the direction of main ice flow. This behavior is in accord with the observation of a sudden acceleration of the ice due to increased sliding in early summer or following heavy rainstorms.
\end{abstract}

RÉSUMÉ. L'importance de l'eau sous-glaciaire sous pression pour le glissement et le décollement de la glace sur le lit. L'effet de l'eau sous-glaciaire sous pression sur le processus de glissement est examiné à partir d'un paramètre appelé «indice de décollement du lit». Cet indice exprime l'extension relative des cavités formées en combinant les effets de la variation des contraintes perpendiculaires au lit au passage des ondulations (Kamb. 1970) et de la pression d'eau à l'état d'équilibre dans le cheminement décrit par Röthlisberger le long du lit glaciaire. Les données provenant de trois glaciers de formes très variables ont servi à tester la liaison de l'indice de décollement du lit avec les vitesses de glissement qui en découlent. Pour le Columbia Glacier et le flux de glace B dans l'Ouest Antarctique on montre que les hautes pressions de l'eau favorisent le glissement. Des données plus abondantes, provenant du troisième glacier, le Variegated Glacier, permettent de comparer plusieurs formulations possibles d'une «loi de glissement». Une loi-puissance du type de Weertman (avec un exposant voisin de 3 ), modifiée pour tenir compte de l'effet de la pression des eaux sous-glaciaires, apparaît comme étant la meilleure. D'autres formulations, parmi lesquelles le «facteur de lubrification» introduit par Budd (1975) sont après essai rejetées. Des considérations sur les variations dans le temps de l'«indice de décollement du lit» montrent que, sur de courtes échelles de temps exprimées en jours ou en semaines les variations de la pression de l'eau peuvent dominer le processus de glissement. Un accroissement rapide de l'ordre de grandeur du débit liquide entraine un accroissement momentané 100 fois plus fort de la pression de l'eau. Un régime hydraulique à deux modes est mis en évidence pour l'écoulement d'eau transversalement à la direction principale du flux de glace. Ce comportement est en accord avec l'observation de l'accélération de la glace consécutif à un glissement accru au début de l'été ou après les grosses chutes de pluie.

Zusammenfassung. Die Bedeutung unter Druck stehenden, subglazialen Wassers für die Ablösung und das Gleiten am Gletscherbett. Die Wirkung unter Druck stehenden, subglazialen Wassers auf den Gleitprozess wird mit Hilfe eines Parameters untersucht, der den Namen „Bettablösungsindex” erhält. Dieser Index beschreibt das relative Ausmass der Hohlraumbildung durch Kombination der Wirkungen von Veränderungen der Spannung senkrecht zum Untergrund über Unebenheiten (Kamb, 1970) und eines stationären Wasserdrucks in einem Röthlisberger-Kanal am Gletscherbett. Daten von drei Gletschern sehr verschiedener Grösse werden zur Bestimmung der Korrelation des Bettablösungsindex mit abgeleiteten Gleitraten herangezogen. Für den Columbia Glacier und den Eisstrom B in West-Antarktika lässt sich zeigen, dass hoher Wasserdruck das Gleiten verstärkt. Vollständige Daten vom dritten Testgletscher, dem Variegated Glacier, werden zum Vergleich einiger möglicher Formulierungen eines „Gleitgesetzes” benutzt. Ein Potenzgesetz vom Weertman-Typ (Exponent c. 3), modifiziert hinsichtlich der Wirkung des subglazialen Wasserdrucks, erweist sich als günstigstes. Andere Formulierungen, 
darunter die von Budd (1975) benutzte „Schmierungsfaktor”-Hypothese, werden versuchsweise abgelehnt. Eine Betrachtung der zeitlichen Änderungen des Bettablösungsindexes zeigt, dass in kurzen Zeitabschnitten von Tagen und Wochen die Änderungen des Wasserdrucks den Gleitprozess beherrschen können. Ein schnelles Anwachsen der Wasserzufuhr um eine Grössenordnung bewirkt vorübergehend eine hundertfache Zunahme des Wasserdruckes. Für den Wasserfluss quer zur Hauptrichtung des Eisstromes lässt sich ein bi-modules hydraulisches Verhalten feststellen. Daraus mag die Beschleunigung des Eises durch erhöhtes Gleiten, das im Frühsommer oder nach heftigen Regenfällen eintritt, zu erklären sein.

\section{INTRODUCTION}

Many glaciers slide over their beds. Surging glaciers are examples of situations in which sliding dominates the ice motion, but many "normal" glaciers also exhibit appreciable sliding motion (Agassiz, 1847; Hodge, 1974; Elliston, unpublished). There have been numerous theories proposed which predict sliding velocity from various geometrical aspects of a glacier (Weertman, 1964; Lliboutry, 1968; Kamb, 1970; Morland, 1976[a], [b]). Usually the primary parameters of these theories are the shear stress at the base, raised to some power, and the bed roughness. The role of subglacial water, if considered at all, is commonly constrained to a thin film between ice and rock thus eliminating any local shear stress along the interface. Meier (1968) used field measurements from Nisqually Glacier to show that a simple relationship between these parameters does not exist there. Haefeli (1970) calculated that on Unteraargletscher over 125 years the mean sliding velocity decreased while the basal shear stress remained relatively unchanged. Thus basal stress and bed roughness are not the only important parameters. Before an adequate theory of sliding can be developed the most critical parameters involved in the process must be identified.

It has long been suspected that pressurized subglacial water plays an active role in basal sliding (Weertman, 1964; Lliboutry, 1979). There is ample field evidence which suggests such an effect. Increases of glacier motion during the summer melt season or following heavy rainstorms have been observed (Agassiz, 1847; Bindschadler and others, 1978; Iken, [1978]; Elliston, unpublished). Direct observations of water pressure in bore holes (Engelhardt, 1978) indicate that, at least locally, pressurized subglacial water affects sliding speed.

Subglacial water is expected to concentrate in cavities on the down-glacier side of bedrock rises where the normal stress of the ice against the rock is lowest. The size and extent of cavities ought to depend on the water pressure, basal geometry, and local stress conditions (Lliboutry, 1968). The precise nature of the connection between sliding and cavitation is still a matter of contention: Iken (1981) argues that the highest sliding rates occur during the growth phase of the cavities, while others hold to the classical view that sliding rates are higher the larger the extent of cavitation. No attempt is made here to resolve these differing views; however, the assumption is made that some connection exists. In this paper, the concept is developed that, using field data, regions of extensive bed separation by cavity formation can be predicted by defining a "bed separation index" which takes account of the longitudinal variations of basal stress and water pressure. Water pressures are calculated from the conduit theory developed by Röthlisberger (1972). It is shown that this bed separation index corresponds better with the expected longitudinal variation of sliding velocity than does the basal stress alone for three field cases. Data from one glacier are used to examine critically a number of "sliding laws". Finally, the analysis is extended to a consideration of possible transverse variations of water pressure and bed separation and an interesting behavior is described which provides a possible explanation of 
the sudden onset of sliding that frequently occurs in early summer or perhaps even the release of glacier surges.

\section{BED SEPARATION INDEX}

The normal stress exerted by the ice on the bed varies across undulations of the bed with the minima occurring on the leeward (down-glacier) sides. In Kamb's theory of basal sliding, the r.m.s. value of the deviation of the normal stress $P$ from its mean is

$$
\left\langle(P-\langle P\rangle)^{2}\right\rangle^{1 / 2} \equiv\left\langle P_{0}^{2}\right\rangle^{1 / 2}=\frac{\sqrt{3}}{\pi^{2} \sqrt{2}} \frac{\tau}{G \xi}
$$

(Kamb, 1970, equation 118). In Equation (1), $\tau$ is the basal shear stress, $\xi$ the bed roughness, and $G$ is a parameter close to unity that accounts for the variation of ice viscosity with stress in the basal layers. The mean normal stress is

$$
\langle P\rangle=\rho g H \cos ^{2} \alpha
$$

where $H$ is the vertical depth, $\rho$ the density of ice, $g$ the gravitational acceleration, and $\alpha$ the surface slope. From Equation (1) it can be seen that if either the basal stress is high enough or the bed roughness low enough, the magnitude of the stress variation could equal $\langle P\rangle$ causing separation of the ice from the bedrock on the leeward sides of the bumps. In this paper we will be more concerned with the variation of $P$ than with its precise value anywhere.

When subglacial water at a pressure $P_{\mathrm{w}}$ is present, separation of the ice from the bed will take place wherever

$$
P \leqslant P_{\mathrm{w}}
$$

or, equivalently, wherever

$$
-P_{0} \equiv\langle P\rangle-P \geqslant\langle P\rangle-P_{\mathrm{w}} \equiv N_{\text {eff }} .
$$

The expression on the right-hand side, $\langle P\rangle-P_{\mathrm{w}} \equiv N_{\mathrm{eff}}$ is termed the "effective normal stress". Using averaged values of $P_{0}$ and $N_{\text {eff }}$, it is clear that the likelihood or extent of separation will increase as $-\mathrm{P}_{0}$ is increased and $N_{\text {eff }}$ is decreased. To permit an examination of these two effects, a "bed separation index" $I$ is defined as

$$
I \equiv \tau / N_{\mathrm{efr}}
$$

This index is a measure of the relative amount of bed separation occurring along the longitudinal center-line of a glacier assuming that $\xi$ and $G$ are constant (cf. Equation (1)). If $N_{\text {eff }}$ equals zero, the glacier is afloat and $I$ is infinite. When separation starts, $I$ has a certain value greater than zero which depends on the bed roughness. Because the calculated values of $I$ are not simply proportional to the degree of separation, the numerical values of $I$ cannot be used quantitatively in a simple way.

To calculate $I$ along the glacier's length, we must know how $\tau$ and $N_{\text {eff }}$ (or $P_{\mathrm{w}}$ ) vary. This requires knowledge of the surface and bed elevation profiles. The basal shear stress is calculated as

$$
\tau=f \rho g \overline{\sin \alpha} H
$$


(Nye, 1952), where $H$ is the surface normal depth, $f$ is a shape factor to account for the drag of the valley walls, and $\alpha$ is the surface slope; the bar denotes a longitudinal averaging over a distance of ten to twenty times the depth to account approximately for longitudinal stress gradients in the ice (Budd, 1968).

The method used to calculate $P_{\mathrm{w}}$ is to adopt Röthlisberger's (1972) theory of subglacial water flow. It contains a number of simplifying assumptions; two major ones are steady-state water flow confined to a single straight channel of circular cross-section completely surrounded by ice, and no transport of heat by the water. Despite these simplifications, the theory is a useful first step for predicting the longitudinal variations of water pressure. The governing equation is

$$
T^{11 / 8}-0.316 T^{3 / 8}\left(\frac{\mathrm{d} P_{\mathrm{w}}}{\mathrm{d} x}\right)=D k^{-3 / 4}(n B)^{-n} Q^{-1 / 4}(\cos \beta)^{-11 / 8}\left(P-P_{\mathrm{w}}\right)^{n}
$$

where

$$
T=\left(\frac{\mathrm{d} P_{\mathrm{w}}}{\mathrm{d} x}\right)+\rho_{\mathrm{w}} g \tan \beta
$$

(Röthlisberger, 1972, equation 20), $P$ is the mean stress, $P_{\mathrm{w}}$ the water pressure, $\rho_{\mathrm{w}}$ the density of water, $\beta$ the bed slope, $D=3.63 \times 10^{10} \mathrm{~N} \mathrm{~m}^{-2}$, a collection of constants related to material properties of water and ice, $k=10 \mathrm{~m}^{1 / 3} \mathrm{~s}^{-1}$, the roughness coefficient of the conduit wall, $n$ and $B$ the ice flow parameters, $n$ being the stress exponent and $B$ a coefficient with units of bar $\mathrm{s}^{1 / n}$, and $Q$ the water discharge of conduits in $\mathrm{m}^{3} \mathrm{~s}^{-1}$. The $x$-axis is horizontal and curvilinear following the longitudinal center-line. The term $T$ in Equation (6) is the force driving the water through the conduit along the bed. $D, k, n$, and $B$ are physical parameters, $\beta(x)$ and $P(x)$ are calculated from a specific glacier geometry, and $Q(x)$ can either be measured or estimated using an assumed ablation rate averaged over the surface (assuming no intraglacial storage). By specifying the water pressure at a single point, usually at the terminal portal, integration of Equation (6) yields the longitudinal profile of $P_{\mathrm{w}}(x)$. It is important to emphasize that the water pressure calculated in this manner is not likely to give the actual water pressure at any particular point along the bed at any particular time; Equation (6) represents the steady-state situation for a single conduit transporting all the subglacial water. The calculated water pressure in a single conduit will be less than if the water were transported through a system of conduits. Nevertheless, this approach provides a useful approximation to the pattern of longitudinal variation of water pressure and its relationship to water discharge and glacier geometry.

\section{TEST OF BED SEPARATION INDEX AS AN INDICATOR OF SLIDING VELOCITY}

\section{Variegated Glacier}

The surge-type Variegated Glacier was chosen for the initial test of the bed separation index concept because sufficient information exists on the geometry (Bindschadler and others, 1977) and the inferred sliding velocity (Bindschadler and others, 1978) to calculate the necessary parameters (Equations (1) through (6)). Figure 1 presents the results. The summer water discharge was estimated from a terminal discharge of $10 \mathrm{~m}^{3} \mathrm{~s}^{-1}$ at atmospheric pressure, a head discharge of zero, and a linear relation between ablation and altitude. In these cases, $n=4.2$ and $B=96.1$ bar s$^{1 / n}$ (Glen, 1955). The winter discharge was assumed to be two orders of magnitude 

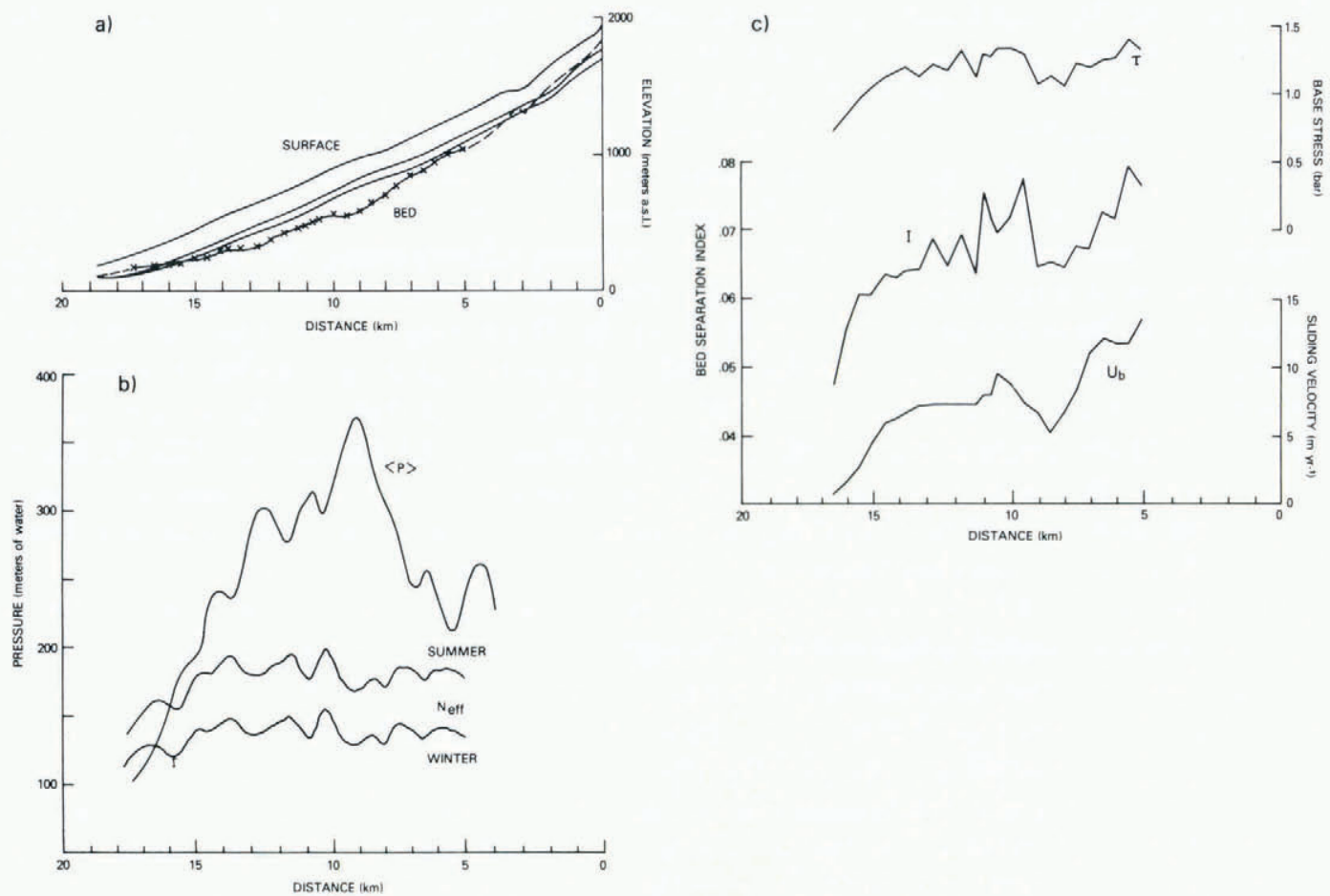

Fig. 1. Longitudinal center-line profiles of Variegated Glacier: (a) surface and bed elevations (X's mark seismic reflection measurements) and calculated hydraulic grade lines for winter (upper) and summer (lower); (b) mean stress $\langle P\rangle$ (Equation (2)) and effective normal stress $N_{\mathrm{eff}}$ (Equation (3)), for summer and winter; (c) base shear stress $\tau$ (Equation (5)), bed separation index I (Equation (4)), and inferred average 1973 summer sliding speed $U_{\mathrm{b}}$ (Bindschadler and others, 1978). Distance is from head of glacier.

lower than the summer discharge. Figure la illustrates many general characteristics of the theoretical water-pressure distribution for glaciers. The hydraulic grade line (which represents the water pressure as a column of water of appropriate height above the bed) tends to parallel the surface (Röthlisberger, 1972). This is a consequence of the compensation of the pressure gradient term $\mathrm{d} P_{\mathrm{w}} / \mathrm{d} x$ for variations in the gravitational driving term $\rho_{\mathrm{w}} g \tan \beta$ in Equation (6). The figure also shows that the grade line is not sensitive to the boundary value of $P_{\mathrm{w}}$ except near that boundary (within a distance equal to a few ice thicknesses). The small variation in the summer and winter grade lines (about $45 \mathrm{~m}$ ) emphasizes how insensitive $P_{\mathrm{w}}$ is to large variations in $Q$ (first pointed out by Röthlisberger, 1972). It must also be noted, however, that the calculated water pressures are higher in the winter while the sliding is low, not in the summer when the sliding is high. This apparently contradictory result is a consequence of the asumption of steadystate flow; water pressure decreases as the water discharge increases (Röthlisberger, 1972). The transient pressure response will, of course, be in the opposite direction; an increase in discharge causes an initial increase in pressure. A discussion of transient effects appears in a later section, but we pause here to reiterate that our concern is with examining the longitudinal variations of suspected crucial parameters rather than their absolute magnitudes.

Because the winter and summer grade lines are parallel, so are the corresponding profiles of 
$N_{\text {eff }}$ (Fig. 1b). The small-scale deviations in both $N_{\text {eff }}$ profiles are caused by variations in the bedrock; because the grade line parallels the surface, a bedrock depression causes an equal increase in both the ice and water columns but since water is more dense than ice, $N_{\text {eff }}$ will decrease (see Equation (2)). The large-scale variation is a gradual decrease from 5 to $10 \mathrm{~km}$, then a higher nearly constant value to $15 \mathrm{~km}$ followed by a decrease toward the terminus.

Figure 1c compares the profiles of $\tau$ (Equation (5) with a two kilometer slope-averaging length), $I$ (Equation (4)), and $U_{\mathrm{b}}$, the inferred basal sliding velocity during the 1973 summer. The two kilometer average appeared to account adequately for the effect of longitudinal stress gradients (see Bindschadler and others, 1977, fig. 9). The sliding velocity was inferred as the difference between the measured summer velocity and a predicted velocity profile. The predicted velocities were calculated from known winter (non-sliding) profiles of velocity and glacier geometry and the measured summer elevation profile (Bindschadler and others, 1978). Values of $\tau$ and $I$ were calculated only where the depth was measured by seismic reflection techniques, approximately every $500 \mathrm{~m}$ (Figure 1a). At these locations, values of $f$ were estimated from Nye's (1965) calculations of rectilinear flow in a parabolic channel. Although Nye's calculations assumed no sliding, they were nevertheless considered to be applicable since the contribution of annually averaged sliding velocity to the total velocity was less than $5 \%$. In Figure 1c the three profiles appear similar because $N_{\text {eff }}$ is nearly constant over the glacier length. The major difference between the $I$ and $\tau$ profiles is in the upper glacier where the lower $N_{\text {eff }}$ values produce a larger longitudinal gradient in the $I$ profile than in the $\tau$ profile. For this particular glacier, this region is the most important because the sliding velocities are highest here and it is also the suspected trigger zone of the surges of Variegated Glacier (Bindschadler and others, 1977). Although hardly definitive (perhaps due to the relatively small sliding velocity), the better agreement of the $I$ profile (rather than the $\tau$ profile) to the $U_{\mathrm{b}}$ profile suggests a discernible effect from water pressure. This question is studied more quantitatively in a later section.

\section{Columbia Glacier}

A second test case, Columbia Glacier near Valdez, Alaska, provides an example where sliding dominates the glacier motion over the near-terminus region. Columbia Glacier is a tidewater glacier with a dominant tributary almost $67 \mathrm{~km}$ long. Surface and bedrock elevations were obtained from data collected by the U.S. Geological Survey (Mayo and others, 1978 and a personal communication from L. A. Rasmussen). A ten-kilometer averaging length for surface slope and $f=0.8$ were used in Equation (5). For the water-pressure calculations, $n=3$ and $B=580$ bar s $^{1 / 3}$. The water discharge was calculated from an annually averaged ablation rate which decreased linearly with altitude. The values of the water discharge and water pressure at the terminus were $103 \mathrm{~m}^{3} \mathrm{~s}^{-1}$ and $134 \mathrm{~m}$ of water (the depth of the bed below sea-level) respectively. Figure 2 summarizes the results. While the basal stress profile shows a gradual decrease with distance, the profile of $N_{\text {eff }}$ is more step-like; generally high before the $40 \mathrm{~km}$ mark and low beyond $40 \mathrm{~km}$. Near the terminus, $N_{\text {eff }}$ is sometimes negative. The resulting profile of $I$ is nearly constant over the majority of the glacier but below $55 \mathrm{~km}$ is dominated by the very low values of $N_{\mathrm{eff}}$. No direct measurements of sliding velocity are available, but the seasonal change in surface velocity $\Delta U$ can be considered as an estimate of the lower bound of sliding and probably preserves the spatial variation of sliding as well. Thus, for comparison, Figure 2 includes a profile of $\Delta U$ from $49 \mathrm{~km}$ to the terminus for the 1977-78 balance year. This profile illustrates the rapid acceleration of the ice over the last few kilometers as the terminus is 


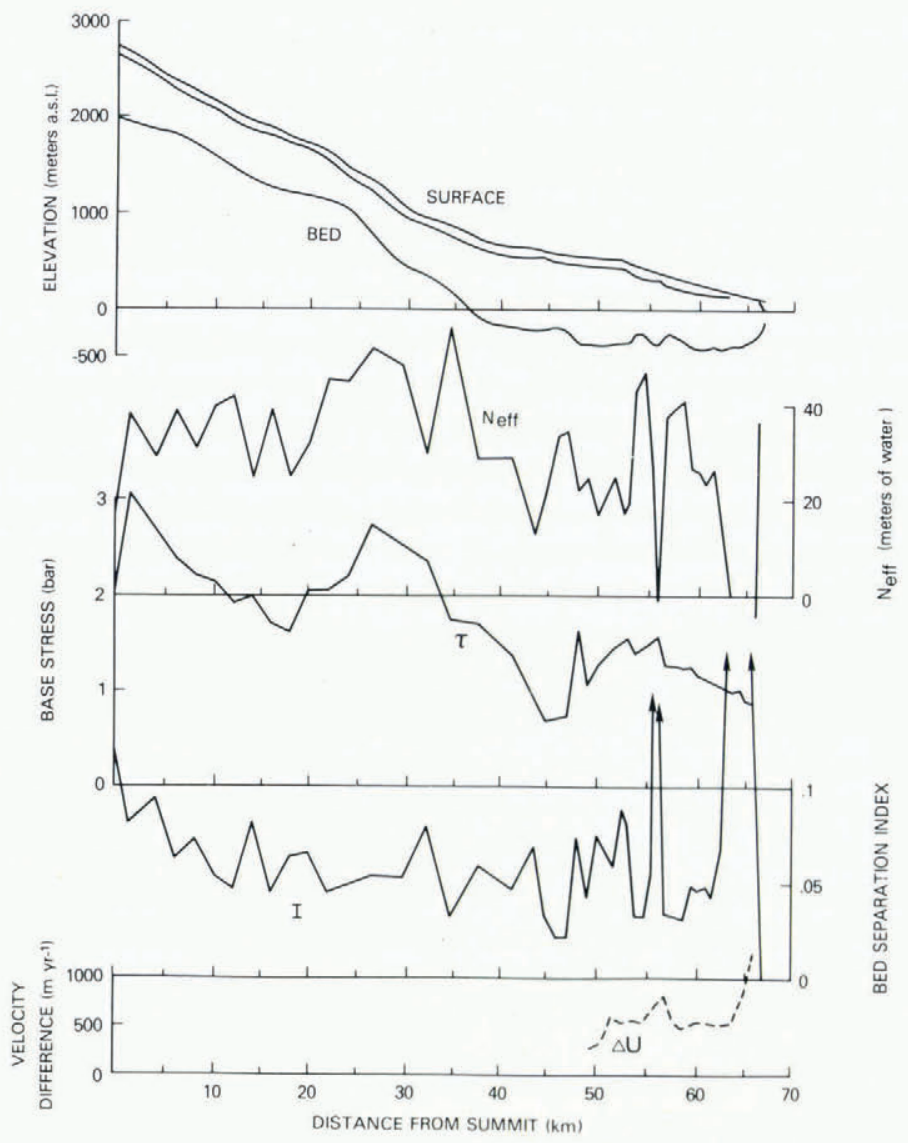

Fig. 2. Longitudinal center-line profiles of Columbia Glacier: surface, bed, and hydraulic grade-line elevations; effective normal stress, $N_{\mathrm{eff}}$ (Equation (3)), base shear stress $\tau$ (Equation (5) using a ten-kilometer slope average); bed separation index I (Equation (4)), and seasonal velocity difference 1977-78, $\Delta U$.

approached. It is this feature, unquestionably a result of increased sliding as the ice is forced up the slope of the shoal, which is well matched by the vanishing $N_{\text {eff }}$ and completely missed by the decreasing $\tau$ values.

The physical interpretation of a negative $N_{\text {eff }}$, or a region where Equation (6) is not soluble, is that a subglacial conduit is not stable in this region. The water is at such a high pressure, exceeding the ice overburden pressure, that it must flow along the bed as a sheet, decoupling the ice from the bed. Such a "maximum lubrication" situation would suggest the presence of very rapid sliding. According to the calculations, just before emerging from underneath the glacier, conduits once again become stable (see Fig. 2). Observations show that one main outlet stream emerges from the glacier but that its position changes with time. This is consistent with the above conclusion of regimes of stable and unstable conduits.

An interesting question to investigate is what role this particular distribution of water pressure plays in the dynamic processes going on at the terminus of a tidewater glacier. The termini of tidewater glaciers are only stable if they end in relatively shallow water (Meier and 
others, 1980). Thus this class of glaciers can advance only by moving the moraine shoal in unison with the terminus, a process Post (unpublished) estimates can take place only at a rate of about one kilometer per century. Since all tidewater glaciers exhibit shallow surface slopes near the terminus while ground-based glaciers (especially advancing ones) have more pronounced terminal slopes, it is interesting to consider the different hydraulic regimes that result from each case. In Figure 3, the lower $30 \mathrm{~km}$ of Columbia Glacier is shown with two different surfaces: the true (1977-78) surface and a hypothesized surface with steeper surface slopes near the terminus. No parameters were changed from Figure 2 except that the bedrock rises between the 50 and $60 \mathrm{~km}$ marks (see Fig. 2) have been removed; they are not crucial for the present study. It is clear from the corresponding $N_{\text {eff }}$ profiles in Figure 3 that for the thicker snout, conduits are always stable which, in turn, suggests a lower sliding velocity. A large sliding velocity is probably required even for the non-advancing tidewater glacier to supply enough subglacial material to balance the continual erosion of the shoal by the sea and the glacier. Thus, tidewater glaciers represent a case where the glacier dynamics are controlled by the subglacial hydraulics. The high water pressures required for rapid sliding are consistent only with a low surface-slope.

\section{Ice Stream B}

Another place that sliding glaciers with low surface slopes occur is in the ice streams and outlet glaciers of Greenland and Antarctica. As a final test case, we examine Ice Stream B in West Antarctica. Using data presented by Rose (unpublished), a flow line was constructed from the up-stream reservoir area along this ice stream to the grounding line at the Ross Ice Shelf (lat. $83.4^{\circ} \mathrm{S}$., long. $102^{\circ} \mathrm{W}$. to lat. $83.7^{\circ} \mathrm{S}$., long. $140^{\circ} \mathrm{W}$. and then to lat. $84.1^{\circ} \mathrm{S}$., long. $155^{\circ} \mathrm{W}$.). Although the basal conditions are not well known, rough estimates of a

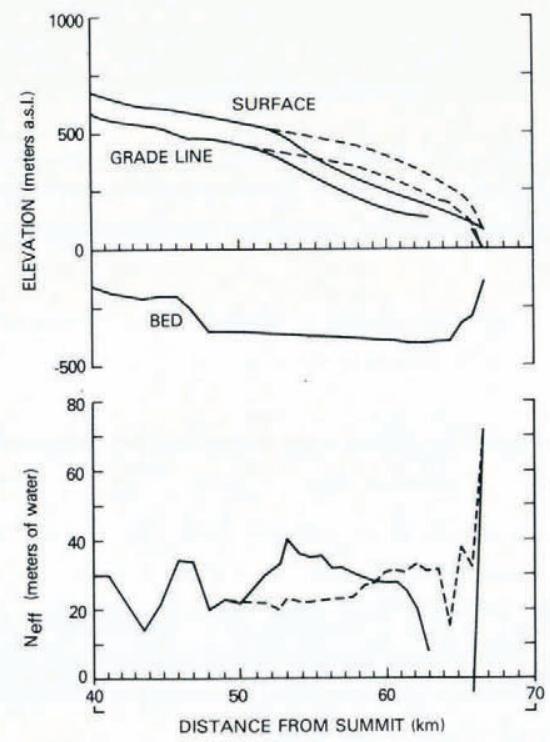

Fig. 3. Predicted hydraulic conditions over lower reach of Columbia Glacier for actual 1977-78 surface (solid lines) and for hygpothesized thicker snout with steeper terminus slope (dashed lines). In both cases bed has been smoothed (see Fig. 2). 
hypothetical water-flux distribution were made by assuming an average shear stress of 0.1 bar and an average sliding velocity of $1000 \mathrm{~m}_{\text {year }}^{-1}$ which resulted in a melt rate of $3 \mathrm{~cm} \mathrm{year}^{-1}$ by frictional heat. Assuming a surface area of $10^{11} \mathrm{~m}^{2}$ gives a total discharge of $100 \mathrm{~m}^{3} \mathrm{~s}^{-1}$ at the grounding line. Two cases on either side of this value were examined $\left(10 \mathrm{~m}^{3} \mathrm{~s}^{-1}\right.$ and $\left.1000 \mathrm{~m}^{3} \mathrm{~s}^{-1}\right)$. The water flux was assumed to be distributed linearly from $40 \mathrm{~km}$ below the summit to the grounding line.

If only a portion of the bedrock is warm, then that segment up-stream of the thermal boundary is a region where $N_{\text {eff }}=\langle P\rangle$ and $P_{\mathrm{w}}=0$. The flow parameters $n=3$ and $B=$ 580 bar s$^{1 / 3}$ were chosen since the basal ice is warm over at least part of the region (Rose, 1979). Figure 4 shows the calculated profiles of $P_{\mathrm{w}}$ and $N_{\mathrm{eff}}$ for the case of low water discharge. The high subglacial mountains intersected by the chosen flow line created the discontinuities in the profiles similar to that caused by the terminal shoal underneath Columbia Glacier. Because the

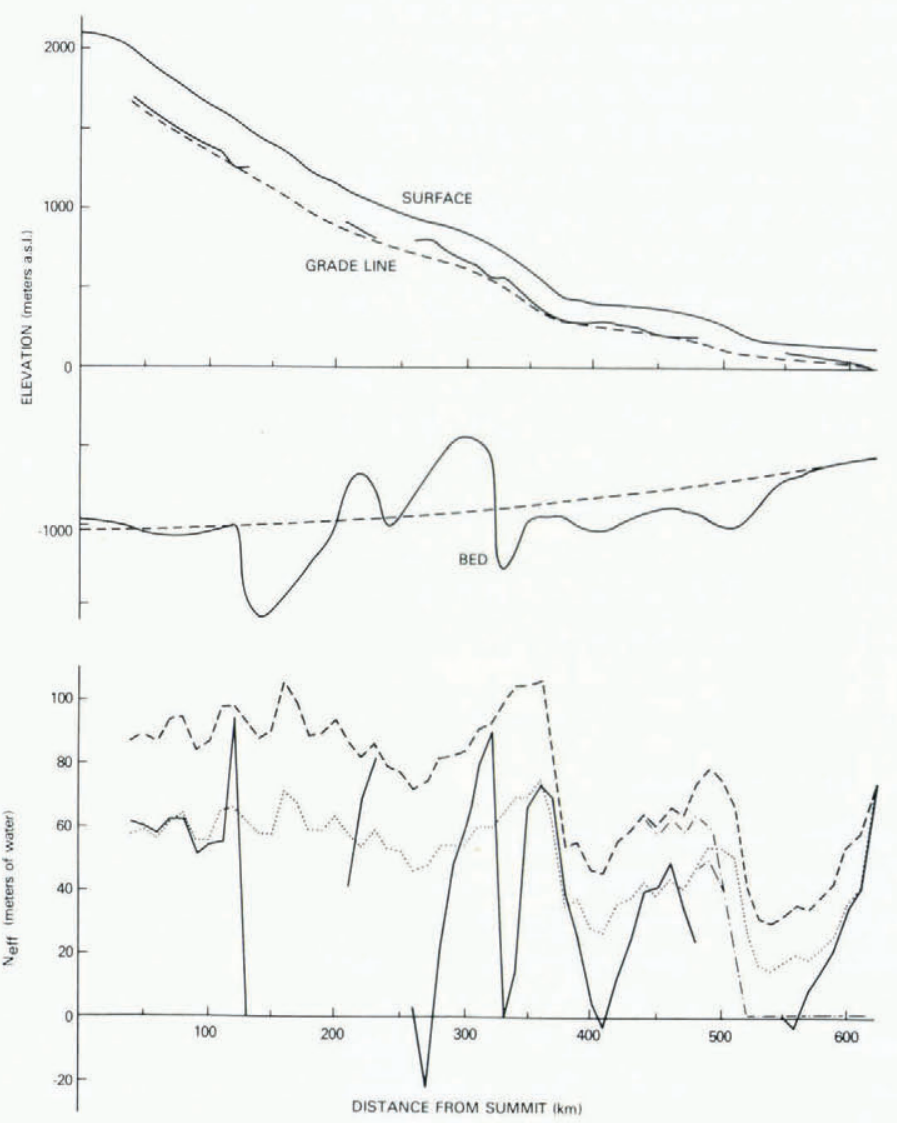

Fig. 4. Predicted hydraulic conditions for Ice Stream B flowline. Solid-lined grade line and $N_{\mathrm{eff}}$ apply to the case with irregular bed and higher water discharge (see text). Dashed lines are for the case with smoothed bed and higher water discharge. Dotted profile of $N_{\mathrm{eff}}$ is for the case with smoothed bed but lower water discharge. Two cases for the exiting water pressure are shown: beyond $500 \mathrm{~km}$, dashed or dotted lines apply to a $550 \mathrm{~m}$ column of water (the submarine ice depth at the grounding line) and the dot-dashed lines apply to a floating grounding line (where the water pressure equals a column of water $625 \mathrm{~m}$ high). 
majority of these mountains are isolated, enabling the water to flow around them, the calculations were repeated (for both the high and low water discharges) for a smoothed bedrock profile (Fig. 4). This simplification does not affect the general profile of $N_{\text {eff }}$ but prevents gaps in the profile caused by these large mountains. Again the profile of $N_{\text {eff }}$ is step-like with two major steps at 370 and $510 \mathrm{~km}$. The positions of these two steps coincide with inflection points in the surface. The first step agrees well with the up-stream boundary of the ice stream shown by Rose (1979, fig. 1); a suggestion previously made by Hughes (1977).

Two choices were made for the exiting water pressure at the grounding line. Floatation required a pressure of $625 \mathrm{~m}$ of water but recent research by Sanderson (1979) suggests that the hinge zones of ice shelves are not in hydrostatic equilibrium. Thus a second case corresponding to a water pressure of $550 \mathrm{~m}$ of water (the thickness of ice beneath sea-level at the grounding line) was also used. In either case the effect was local, limited to the $100 \mathrm{~km}$ adjacent to the grounding line. In the floatation case, floatation extended an additional $100 \mathrm{~km}$ up-stream. This suggests the existence of a broad "grounding zone" of floating ice rather than a narrow region. On the other hand, the second case corresponds to a grounding line where the ice is lifted from the bedrock by the cantilever effect of the ice shelf further down-stream which is truly floating.

From the geometry of Figure 4 it is clear that the shear stress decreases towards the ice shelf since both regional surface slope and ice depth decrease with distance. At the same time, however, it is known that the ice is accelerating (although specific measurements are sparse). Double-valued sliding relationships have been used to reconcile this apparent paradox (Budd, 1975), but the calculated profile of $N_{\text {eff }}$ in Figure 4 supports the idea that the acceleration is a result of the subglacial water pressure.

The results of the three test cases make the point that, by including a simple parametrization of pressurized subglacial water, the variation of sliding velocity can be accounted for by a physically justifiable mechanism. For near-zero water pressures, a Weertman-type sliding law appears adequate, but as water pressure increases, the water controls the sliding process. The lower value of the average basal shear stress is only a result of the separation, which causes stress concentrations in areas where ice is still in contact with the bed. It is these stress concentrations that control the sliding velocity.

\section{POSSIBLE SLIDING RELATIONSHIPS}

What we ultimately seek is a "sliding law" which allows us quantitatively to predict the sliding velocity from the glacier geometry. In the three cases above, it has been shown that the distribution of water pressure is strongly dependent on the glacier geometry and less dependent on either water discharge or boundary conditions. Unfortunately, the only complete data set (i.e. of $\tau, N_{\text {eff }}$, and $U_{\mathrm{b}}$ ) is for Variegated Glacier, the case with the lowest sliding. In addition, any quantitative significance to the values of $N_{\text {eff }}$ should be viewed with caution. Nevertheless, because numerical models of ice flow need a relationship which can adequately predict sliding velocity from glacier geometry, a cursory examination of various possible relationships is justified.

Table I lists the four relationships considered. Each sliding "law" required two parameters. To determine the "best-fit" parameters in each case, wide ranges of each parameter were tried. For each pair of parameters, the residuals between the predicted sliding velocity and inferred sliding velocity were calculated for 26 values of $\tau, N_{\text {eff }}$, and $U_{\mathrm{b}}$ spaced along Variegated Glacier. 

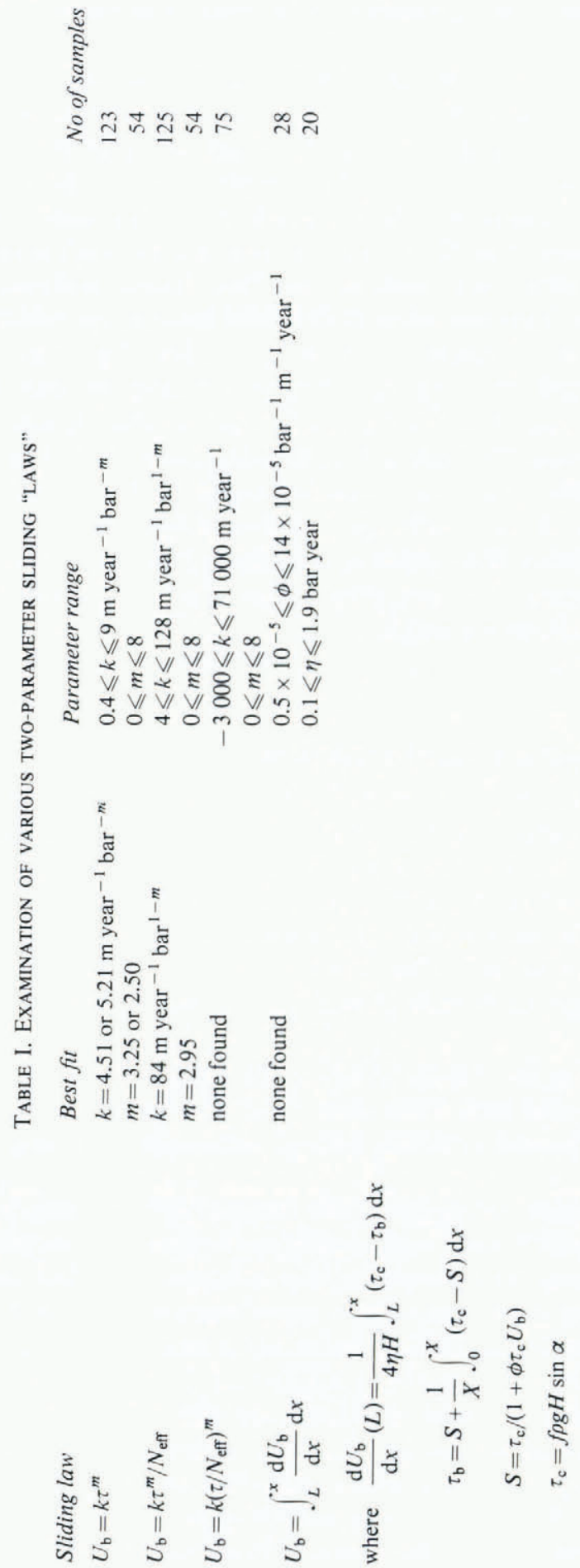
The best fit was then defined as the minimum root-mean-square (r.m.s.) of the residuals for each "law".

The first case in Table I, proposed by Weertman (1964), produced two r.m.s. minima of $1.71 \mathrm{~m} \mathrm{year}^{-1}$. In the original work, Weertman determined that $m$ should be somewhere between 2 and 3. This fit appears quite good, suggesting that Weertman's law is adequate for moderate sliding. However, in the next case, Weertman's law was modified to take account of the effect of water pressure and this resulted in a single minimum with a lower r.m.s. ( $\left.1.56 \mathrm{~m}_{\text {year }}{ }^{-1}\right)$. In addition, this latter case (i.e. with $N_{\text {eff }}$ included) predicted the higher sliding velocities better, an effect not reflected in this rough analysis. Further, laboratory experiments of sliding by Budd and others (1979) have led to an empirical relationship equivalent to the second case in Table I with $m=3$ and $k / N_{\text {eff }}=1800 / Z \mathrm{~m}^{2}$ year $^{-1}$ bar $^{-3}$ where $Z$ is the glacier depth (see Budd and others, 1979, p. 167). This is consistent with the results in Table I.

The last two cases Table I are examples of where no clear minima were found within the ranges of parameters tested. The fourth case in Table I corresponds to the sliding relationship used in numerical modelling of periodic surges (see Budd, 1975, for details).

Although the success of the second case is at best only suggestive, it can still prove useful in numerical models of glacier flow where it is necessary to use velocities averaged over time intervals of months to years. Certainly more data of this type are needed before a more firmly established sliding relationship is possible.

\section{TEMPORAL VARIATIONS OF BED SEPARATION INDEX}

As long as changes occur slowly, the hydraulic system is never far out of equilibrium. In this case, changes in the glacier geometry affect $\tau$ much more strongly than $N_{\text {eff }}$, so the corresponding changes in $I$ are dominated by the altered $\tau$ distribution. This was shown by Bindschadler (unpublished) where, using predictions of the large changes in geometry of the surge-type Variegated Glacier during the quiescent phase, more than $85 \%$ of the change in $I$ was due to the change in $\tau$ (see Bindschadler, unpublished, figs 9.2 and 9.3). For long-term changes in the water discharge, there will be little change in $I$ because $N_{\text {eff }}$ is insensitive to water discharge (see Fig. 1).

On the other hand, for very rapid changes in the water discharge, the conduit has no time to adjust and acts like a rigid pipe. Here, then, there can be a very large change in the water pressure (and $N_{\text {eff }}$ ) and because $\tau$ initially remains unchanged, the changes in $I$ will be dominated by those in $N_{\text {eff }}$.

In between lies the time regime where the conduits are adjusting to changes in geometry, water discharge, and possibly even water temperature. Bore-hole pumping experiments on Blue Glacier indicate that small interconnecting passageways at the bed can alter their geometry within hours (Engelhardt, 1978). The highly variable fluctuations of water levels observed in bore holes (Hodge, 1976; Engelhardt, 1978) indicate that a steady state may never be realized during the summer. It is likely, however, that some equilibrium is attained during the winter when sliding is minimal and fluctuations in water production are small. Thus it is in the summer when the highest water pressures usually occur. A small change in water discharge can cause a tremendous initial change in water pressure (even though the steady-state water pressure will change little). For example, an order-of-magnitude increase in water discharge will result in a hundredfold transient rise in water pressure (see Röthlisberger, 1972, equation (9)). Therefore, 
sudden or intense rainstorms, periods of hot weather, and other phenomena that rapidly alter the production rate of water on a glacier, all have a potentially large effect on the water pressure distribution. The diurnal radiation cycle falls into this category. Thus "summer sliding velocity" is a gross averaging and the behavior of water pressure on all different time scales is involved. Some work aimed at gaining a more quantitative understanding of this transient behavior has already begun (Engelhardt, 1978; Spring and Hutter, 1981).

\section{TRANSVERSE VARIATIONS OF BED SEPARATION INDEX}

So far the approach has considered only longitudinal variations of base stress, water pressure, and the bed separation index. Now we turn our attention to the possible transverse variation of these quantities. By hypothesizing that the subglacial water flows through a main conduit at the lowest point of any transverse section and that additional water joins this main channel through a series of secondary conduits perpendicular to the main one, Equation (6) can be applied to solve for the water pressure along a secondary conduit at the ice-rock interface. A uniform rate of water production at the surface and vertical transit of the water to the secondary channel is assumed. Thus the water discharge increases linearly along the channel from zero at the margin to a maximum at the main conduit. For purposes of calculation, a maximum of $0.03 \mathrm{~m}^{3} \mathrm{~s}^{-1}$ was assumed. As was already mentioned, the solution of Equation (6) is insensitive to $Q(x)$, so the above assumptions are not restrictive. Figure 5 gives the calculated hydraulic grade lines and profiles of $N_{\text {eff }}$ for a parabolic cross-section (half-width to depth ratio of 2) for different water pressures in the main channel. For low water pressures in the main channel the pressure in the secondary channel quickly rises to a near-constant level paralleling the surface. This is a basic characteristic of conduit water flow mentioned earlier.

Only when the hydraulic elevation in the main channel exceeds this nearly constant level does the grade line across the section exceed this constant level establishing a higher, but again, constant level. This behavior was also found to hold for elliptical, rectangular, and V-shaped cross-sections. Thus the hydraulic conditions across most of the section are insensitive to the main channel pressure until this pressure exceeds a critical level and then, as quickly as the secondary conduits can adjust, the hydraulic condition across the entire bed changes.

The water pressure in the conduit rises steadily toward the main channel, due to increasing depth below the surface, except near a main channel at low pressure. The hydraulic grade line, however, may never rise: specifying a positive discharge everywhere forces the driving force (term $T$ in Equation 6) always to be positive. Thus, when the main channel pressure is above the critical level, the grade line cannot decrease to the same elevation as in the cases with lower pressure in the main channel If it were to do this, the result would be that water would flow away from the main conduit; yet even in this case, the basal hydraulics would undergo a dramatic change and the entire bed would experience a pronounced increase in lubrication.

Figure 5 also shows how the effective normal stress varies across the cross-section. For a low main channel pressure, $N_{\text {eff }}$ is a maximum at the channel whereas for high main channel pressure, $N_{\text {eff }}$ is a minimum at the main channel. To calculate the bed separation index we must also know the variation of $\tau$ across the section. This is difficult to know: theoretical calculations by Nye (1965) predict a near-constant $\tau$ across the middle half of a parabolic section when there is no sliding, while from field measurements on Athabasca Glacier, Raymond (1971) calculated 

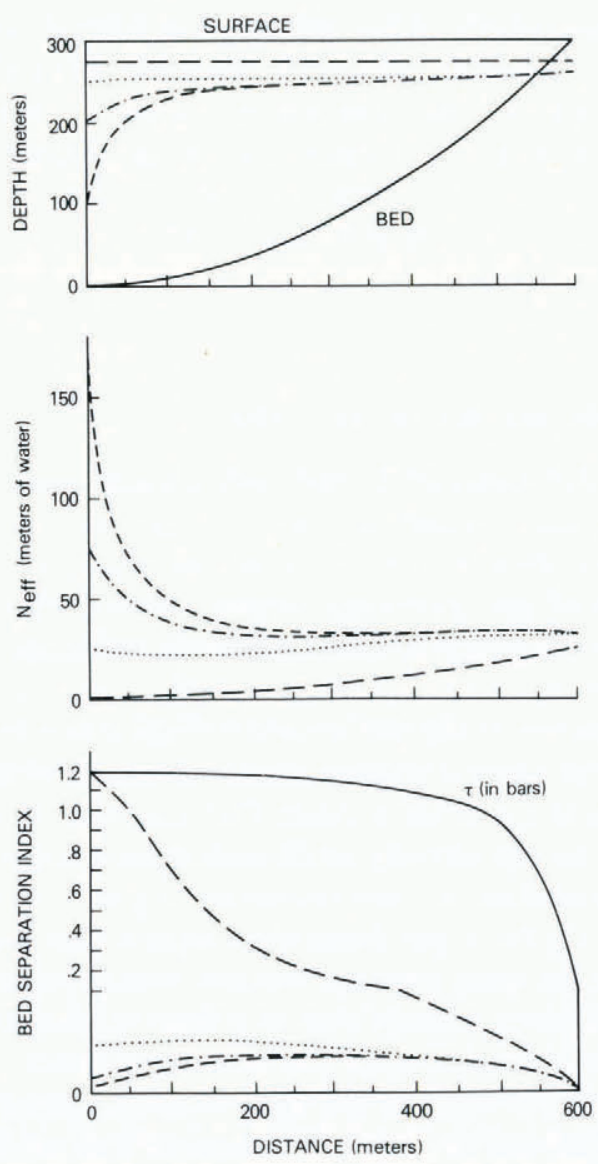

Fig. 5. Transverse variations of hydraulic grade line, effective normal stress, and bed separation index for a parabolic channel section. Different cases, represented by different types of lines, correspond to four different values of main channel pressure (at $x=0)$. Profile of base shear stress $\tau$ is from Nye (1965). Note scale change at $I=0.1$ in the lowermost plot.

a $\tau$ variation different from Nye's in two transverse sections where sliding was significant. The effect of sliding in the Athabasca profiles was to lower the basal shear stress in these areas.

By assuming Nye's no-sliding solution, the calculated transverse profiles of $I$ for the different main conduit pressures are included in Figure 5. For the lower main channel pressures, the maximum of $I$ is not at the main channel but offset by various distances. Also, the variation of $I$ away from the main channel is insensitive to the pressure in the main channel. It is interesting that Raymond's estimates of sliding velocity in the two Athabasca Glacier cross-sections are not at a maximum at the lowest point of the bed either. However, what is even more interesting is that, for the higher main channel pressure, $I$ increases dramatically over the entire section (note the scale change in Fig. 5). It is important to emphasize that the only difference in the profiles of Figure 5 is the main conduit pressure, nothing else. A different distribution of $\tau$ would not significantly change this result. This rapid transition from relatively constant, low values of $I$ to much higher values when the main channel pressure exceeds a critical level is suggestive of the 
rapid onset of sliding that occurs on many glaciers after a period of high water flux into the glacier (Iken, [1978]).

Many observers have noted that during periods of high sliding there is a large amount of water nearby: high levels of water in bore holes, water-filled crevasses, and the concurrent appearance of marginal lakes, but unfortunately, quantitative measurements have not been completed to verify if the hydraulic grade line is as predicted in Figure 5. These predictions are affected very little if the secondary channel does not run perpendicular to the main channel; the tendency for the grade line to parallel the surface is the same. Also, the size of the water collection basin matters little; there is always a critical level of the hydraulic grade line.

\section{SUMMARY}

Pressurized subglacial water appears to play a fundamental role in the sliding process. The bed separation index provides a simple method to combine the effects of base stress and water pressure based on data from two glaciers and one ice stream which vary enormously in size and speed. The quantitative connection between glacier geometry and sliding velocity has not been made here but it appears certain that such a connection will have to include the effects of water pressure.

Over time scales less than years it can be said that the spatial and temporal variations of water pressure play the active role, and basal shear stress the passive role, in basal sliding. It then becomes obvious that water pressure is one of the most fundamental parameters of the sliding process. A clearer understanding of the behavior of water and cavity formation is a prerequisite to understanding sliding. Both field and theoretical studies have been initiated to this end, but more data are necessary to test proposed "sliding laws".

Consideration of the transverse variation of water pressure and bed separation index indicates that, in the main conduit, only a rise of water pressure above a critical level should cause a substantial increase in the separation across the glacier. The duration of the increased sliding would last only as long as it took for the glacier hydraulics to adjust. Therefore, one might expect that, for a sliding episode of the magnitude and duration of a surge, there would also have to exist a sufficiently high basal stress to maintain the necessary degree of bed separation for an extended period of time. This view is consistent with the observations made on Variegated Glacier where both the basal stress and the average summer sliding velocity increased annually through the latter half of the quiescent phase, before the surge occurred (Bindschadler and others, 1978).

MS. received 3 July 1981 and in revised form 10 February 1982

\section{REFERENCES}

Agassiz, L. 1847. Système glaciaire, ou recherches sur les glaciers ..., pt. I. Nouvelles ètudes et expèriences sur les glaciers actuels .... Paris, V. Masson. 2 vols.

Bindschadler, R. A. Unpublished. A time-dependent model of temperate glacier flow and its application to predict changes in the surge-type Variegated Glacier during its quiescent phase. [Ph.D thesis, University of Washington. 1978.|

Bindschadler, R. A., and others. 1977. Geometry and dynamics of a surge-type glacier, by R. [A.] Bindschadler, W. D. Harrison, C. F. Raymond, and R. Crosson. Journal of Glaciology, Vol. 18, No. 79, p. 181-94. 
Bindschadler, R. A., and others. 1978. Sliding velocity of a surge-type glacier during its quiescent phase of motion. [by] R. [A.] Bindschadler, C. [F.] Raymond, W. [D.] Harrison. Materialy Glyatsiologischeskikh Issledovaniy. Khronika. Obsuzhdeniya, Vyp. 32, p. 224-29, 280. [In Russian, p. 109-17, 192-93.]

Budd, W. F. 1968. The longitudinal velocity profile of large ice masses. Union de Géodesie at Géophysique Internationale. Association Internationale d'Hydrologie Scientifique. Assemblee générale de Berne, 25 sept.-7 oct. 1967. [Commission de Neiges et Glaces.] Rapports et discussions, p. 58-77. (Publication No. 79 de l'Association Internationale d'Hydrologie Scientifique.)

Budd, W. F. 1975. A first simple model for periodically self-surging glaciers. Journal of Glaciology, Vol. 14, No. 70, p. 3-21.

Budd, W. F., and others. 1979. Empirical studies of ice sliding, by W. F. Budd, P. L. Keage, and N. A. Blundy. Journal of Glaciology, Vol. 23, No. 89, p. 157-70.

Elliston, G. R. 1973. Water movement through the Gornergletscher. Union Géodésique et Géophysique Internationale. Association Internationale d'Hydrologie Scientifique. Commission de Neiges et Glaces. Symposium on the Hydrology of Glaciers, Cambridge, 7-13 September 1969, p. 79-84. (Publication No. 95 de l'Association Internationale d'Hydrologie Scientifique.)

Engelhardt, H. F. 1978. Water in glaciers: observation and theory of the behaviour of water levels in boreholes. Zeitschrift für Gletscherkunde und Glazialgeologie, Bd. 14, Ht. 1, p. 35-60.

Glen, J. W. 1955. The creep of polycrystalline ice. Proceedings of the Royal Society of London, Ser. A, Vol. 288, No. 1175 , p. $519-38$.

Haefeli, R. 1970. Changes in the behaviour of the Unteraargletscher in the last 125 years. Journal of Glaciology, Vol. 9, No. 56, p. 195-212.

Hodge, S. M. 1974. Variations in the sliding of a temperate glacier. Journal of Glaciology, Vol. 13, No. 69, p. $349-69$.

Hughes, T. J. 1977. West Antarctic ice streams. Reviews of Geophysics and Space Physics, Vol. 15, No. 1, p. 1-46.

Iken, A. [1978.] Variations of surface velocities of some Alpine glaciers measured at intervals of a few hours. Comparison with Arctic glaciers. Zeitschrift für Gletscherkunde und Glazialgeologie, Bd. 13, Ht. 1-2, 1977. p. 23-35.

Iken, A. 1981. The effect of the subglacial water pressure on the sliding velocity of a glacier in an idealized numerical model. Journal of Glaciology, Vol. 27, No. 97, p. 407-21.

Kamb, W. B. 1970. Sliding motion of glaciers: theory and observation. Reviews of Geophysics and Space Physics, Vol. 8, No. 4, p. 673-728.

Lliboutry, L. A. 1968. General theory of subglacial cavitation and sliding of temperate glaciers. Journal of Glaciology, Vol. 7, No. 49, p. 21-58.

Lliboutry, L. A. 1979. Local friction laws for glaciers: a critical review and new openings. Journal of Glaciology, Vol. 23, No. 89, p. 67-95.

Mayo, L. R., and others. 1979. Columbia Glacier stake location, mass balance, glacier surface altitude, and ice radar data, 1978 measurement year, by L. R. Mayo, D. C. Trabant, R. March, and W. Haeberli. U.S. Geological Survey. Open File Report 79-1168.

Meier, M. F. 1968. Calculations of slip of Nisqually Glacier on its bed: no simple relation of sliding velocity to shear stress. Union de Géodésie et Géophysique Internationale. Association Internationale d'Hydrologie Scientifique. Assemblee générale de Berne, 25 sept.-7 oct. 1967. [Commission de Neiges et Glaces.] Rapports et discussions, p. 49-57. (Publication No. 79 de l'Association Internationale d'Hydrologie Scientifique.)

Meier, M. F., and others. 1980. Predicted timing of the disintegration of the lower reach of Columbus Glacier, Alaska, by M. F. Meier [and 7 others]. U.S. Geological Survey. Open File Report 80-582.

Morland, L. W. 1976[a]. Glacier sliding down an inclined wavy bed. Journal of Glaciology, Vol. 17, No. 77, p. 447-62.

Morland, L. W. 1976[b]. Glacier sliding down an inclined wavy bed with friction. Journal of Glaciology, Vol. 17, No. 77 , p. $463-77$.

Nye, J. F. 1952. The mechanics of glacier flow. Journal of Glaciology, Vol. 2, No. 12, p. 82-93.

Nye, J. F. 1965. The flow of a glacier in a channel of rectangular, elliptic, or parabolic cross-section. Journal of Glaciology, Vol. 5, No. 41, p. 661-90.

Post, A. S. Unpublished. Tidal glacier theory. [Written summary of presentation to Pacific Northwest Glaciologists, Tacoma, Washington, 30 November 1973.]

Raymond, C. F. 1971. Flow in a transverse section of Athabasca Glacier, Alberta, Canada. Journal of Glaciology, Vol. 10, No. 58, p. 55-84. 
Röthlisberger, H. 1972. Water pressure in intra- and subglacial channels. Journal of Glaciology, Vol. 11, No. 62, p. $177-203$.

Rose, K. E. Unpublished. Radio echo sounding studies of Marie Byrd Land, Antarctica. [Ph.D. thesis, University of Cambridge, 1978.]

Sanderson, T. J. O. 1979. Equilibrium profile of ice shelves. Journal of Glaciology, Vol. 22, No. 88, p. 435-60.

Spring, U., and Hutter, K. 1981. Conduit flow of a fluid through its solid phase and its application to intraglacial channel flow. International Journal of Engineering Science, Vol. 20, No. 2, p. 327-63.

Weertman, J. 1964. The theory of glacier sliding. Journal of Glaciology, Vol. 5, No. 39, p. 287-303. 